\title{
リチゥム非水溶媒電池用正極活物質としての 無水ピロメリト酸
}

\author{
小梘 勉*; 若松久嗣**, 竹原善一郎**, 吉 沢四郎**
}

\begin{abstract}
1 緒言 (Introduction)
リチウム非水溶媒電池は，小型高エネルギー密度電池 として期待されている.これらの正極活物質に無機化合 物を用いる研究は多いが，有機化合物を用いる研究柱少 なく，p-テトラクロロキノン1)，m-ジニトロベンゼン2 4), ジクロロイソシアヌリック酸昼，2,3-ジクロロ-5, 6ジシアノ-1,4-ベンゾキノン6), フェニレンジアミンク などが報告されているに過ぎない，しかし，いずれも電 解液に可溶性で負極リチウムとの反态による自己放電が 大きく，実用化に対し大きい障害となっている，著者ら は，新しく無水ピロメリト酸が，リチウム非水溶媒電池 用正極活物質になり得ることを見いだしたので報告す る.
\end{abstract}

\section{2 実験方法 (Experimental)}

電解液には，過塩素酸リチウム $1 \mathrm{~mol} \mathrm{dm}{ }^{-3}$ を溶解き せたプロピレンカーボネート (PC) 溶液を, 前報8 と同

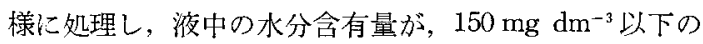
ものを用いた．有機化合物は，市販の試薬を隇圧下，五 酸化リンふん囲気で乾燥したものを用いた。活物質と黒 鉛と党重量比 1:1 の割合で混合し, 成型压 $250 \mathrm{~kg}$ $\mathrm{cm}^{-2}$ でペレット (11 mm $\phi$, 重量 $0.05 \sim 0.10 \mathrm{~g}$ 程度) を作成し，正極合剂とした．対極には白金線，参照極に 銀線*1を用いた Fig. 1 亿示すセルを用い, 単極放電試験 を行なった．試料をセットし少なくとも 3 時間以上静置 した後, 電位が安定していることを確かめ, このときの 電位在開路電圧 (O.C.V.) とした. 実験はすべて室温, ドライボックス中で $0.2 \mathrm{~mA}$ 定電流条件下で行なった.

有機物質 0.005 モルを $25 \mathrm{~cm}^{3}$ の $1 \mathrm{M} \mathrm{LiClO}_{4} / \mathrm{PC}$ 溶 液に溶解させた電解液を用いて自己放電試験を行なっ た.負極には，約 $5 \mathrm{~cm}^{2}$ の板状リチウムを用い，ワニロ

$*$ 烊山大学工学部 (岡山市津島)

** 宗都大学工学部（宗都市左京区吉由本町）

Key zoords : Nonaqueous Lithium Cell, Pyromellitic Dianhydride, Organic Cathode Material, High Energy Cell

*1 液絡には，モレキュラーシーブ $5 \mathrm{~A} ， 1 / 16$ インチをガラ 細管に封したもの在用いた。このようにして作成した参 照極は。溶液組成の変化汇伴う電位の变化を直接に注受け ナ゙、リチウム極仗対して $+2.85 \mathrm{~V}\left(25^{\circ} \mathrm{C}\right)$ の安定した電 位を与える。

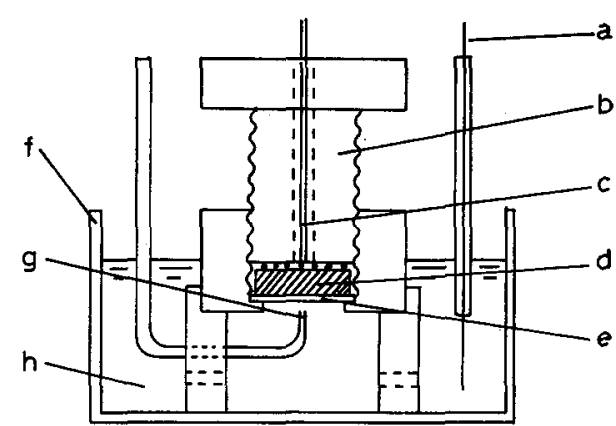

Fig. 1 Experimental cell
a : Counter electrode, $\quad \mathrm{b}:$ Teflon holder
$\mathrm{c}$ : Platinum lead, $\mathrm{d}$ : Cathode mix
e : Separator (Y 121), f : Glass cell
$\mathrm{g}:$ Luggin capillary, $\mathrm{h}$ : Electrolyte

クリップで圧着することにより負極リード線をとった。 正極には，窒素ふ儿团気， $350^{\circ} \mathrm{C} て ゙ 4$ 時間処理を加えた 分光分析用黒鉛（作用面積的 $2 \mathrm{~cm}^{2}$ ) を用い，それぞれ ビーカーセルに挿入, 電池を形成し，一定時間静置*2 し たのち $4 \mathrm{k} \Omega$ 定負荷放電を行ない, 残存容量を測定し自 己放電の難易を調べた。

\section{3 結果及び考察 (Results and Dissussion)}

\section{1 単極放電試駼}

Fig. 2 に無水ピロメリト酸 (PDA) を正極に用いた 場合の単極放電曲線の 1 例を示す. PDA 沙少なくとも 1 分子当り 2 電子以上の還元を受けているものと考えら れ，2電子還元を仮定すれば, 理論容量 $0.246 \mathrm{Ah} \mathrm{g}^{-1}$ となり,リチウムと組み合わせ た場 合, 実測開路電王 $3.12 \mathrm{~V}$, 理論エネルギー密度 $721 \mathrm{Wh} \mathrm{kg}^{-1}$ の電池が期待 できる.

無水マレイン酸 (MAH) を用いた場合も同㥞な放電 㤟線索示した.この場合は少なく上も 1 分子当り 1 電子 以上の還元を受けているものと考えられ，PDA に比べ て分子量が小さいため 1 電子還元を仮定し，リチウムと 組み合わせた場合, 理論エネルギー密度 $780 \mathrm{Wh} \mathrm{kg}^{-1}$ の

*2 静置中心自己放電が淮行する. 静置時間を変化させること により自己放電の難易を知ることができる。 
Capacity $/ \mathrm{F} \mathrm{mol}^{-1}$

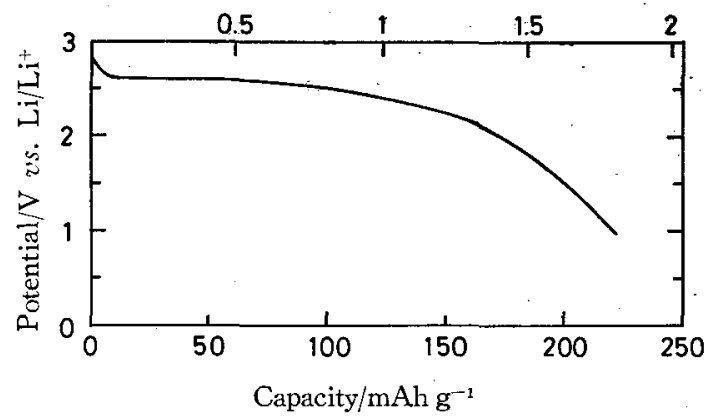

Fig. 2 Half-cell potential discharge curve of pyromellitic dianhydride discharged in $1 \mathrm{M} \mathrm{LiClO}_{4} / \mathrm{PC}$ at a rate of $0.21 \mathrm{~mA} \mathrm{~cm}^{-3}$

電池が期待できる.

同様に，比較のために，2，3 の電子受容性化合物*3， テトラシアノエチレン (TCNE), 2,3-ジクロロ-5,6-ジ シアノ-1,4-ベンゾキノン (DDQ), $m$-ジニトロベンゼ ン $(m$-DNB) についても単極放電曲線を測定した.こ れより求めた理論容量㧍よびりチウムと組合せた場合の 理論エネルギー密度をそれらの実測值その他とともに Table 1 にによとめて示した.

PDA ९ MAH のような有機酸無水物も従来提案さ れている他の有機化合物と同程度の高エネルギー密度電 池用正極活物質として用いらることがわかる.

\section{2 自己放電試験}

Table 1 に示すように，用いた有機化合物は, $1 \mathrm{M}$ $\mathrm{LiClO}_{4} / \mathrm{PC}$ 溶液に溶解する。したがって溶解した有機 化合物が負極リチウムと反応することによる自己放電が 問題となる.そこで 2 で示した自己放電試験用電池*゙を 組立て 4 時間静置 (PDA の場合のみ 32 時閒静置)した 後, $4 \mathrm{k} \Omega$ 定負荷放電を行なった. 得られた放電曲線の 代表例を Fig. 3 亿示す. DDQ, TCNE の場合それぞれ $268 \mathrm{mAh}, 134 \mathrm{mAh}$ の容量（仕込み容量）を持っのに対

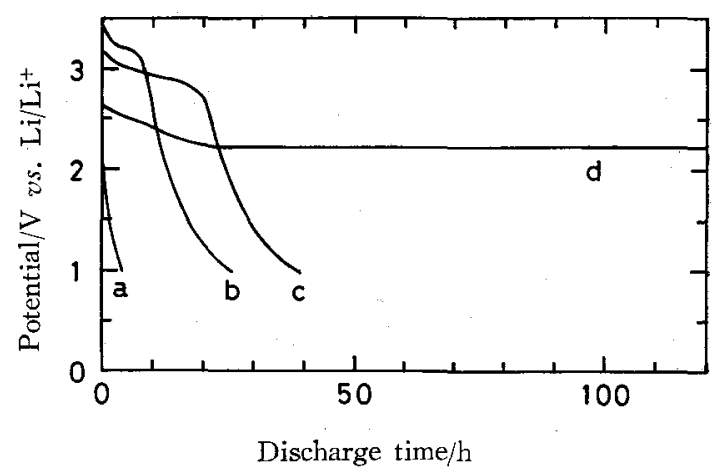

Fig. 3 Discharge curves of some organic compounds dissolved in $1 \mathrm{M} \mathrm{LiClO}_{4}$ /PC at a load of $4 \mathrm{k} \Omega$

Organic compounds : $0.005 \mathrm{~mol} / 25 \mathrm{~cm}^{3}$ of electrolyte, Anode : Lithium $\left(5 \mathrm{~cm}^{2}\right)$, Cathode : Graphite $\left(2 \mathrm{~cm}^{2}\right)$, a: Blank, b: 2,3-dichloro5,6-dicyano-1, 4-benzoquinone, c: Tetracyanoethylene, d: Pyromellitic dianhydride

Table 1 Observed open circuit voltages and capacities and expected energy densities of various organic compounds discharged in $1 \mathrm{M} \mathrm{LiClO}_{4} / \mathrm{PC}$ at a rate of $0.21 \mathrm{~mA} \mathrm{~cm}$

\begin{tabular}{|c|c|c|c|c|c|}
\hline \multirow[b]{2}{*}{ Materials } & \multirow{2}{*}{$\frac{\text { O.C.V. }}{\mathrm{V}}$} & \multicolumn{2}{|c|}{ Capacity } & \multirow{2}{*}{$\frac{\text { Expected }}{\frac{\text { energy density }}{W h \mathrm{~g}^{-1}}}$} & \multirow{2}{*}{$\frac{\text { Solubility }}{\frac{\text { in } 1 \mathrm{M} \mathrm{LiClO}_{4} / \mathrm{PC}}{\mathrm{mol} \mathrm{dm}^{-3}}}$} \\
\hline & & $\frac{\text { (Observed) }}{{\mathrm{Ah} \mathrm{g}^{-1}}^{-1}}$ & $\frac{\text { (Expected) }}{\mathrm{Ah} \mathrm{g}^{-1}}$ & & \\
\hline P D A & 3.12 & 0.22 & $0.246^{* 2}$ & 0.721 & ca 0.07 \\
\hline MAH & 3.06 & 0.28 & $0.273 * 1$ & 0.780 & $>0.1$ \\
\hline TCNE & 3.23 & 0.21 & $0.209 * 1$ & 0.641 & $>0.2$ \\
\hline $\mathrm{DDQ}$ & 3.46 & 0.19 & $0.236 * 2$ & 0.773 & $>0.2$ \\
\hline$m$-DNB & 3.12 & 0.24 & $0.319 * 2$ & 0.914 & $>0.1$ \\
\hline
\end{tabular}

*1 is based on 1 electron transfer per molecule

*2 is based on 2 electrons transfer per molecule

*3 単極放電曲線は, TCNE は 1 電子迩元, DDQ は 1 電子 2 段還元， $m$-DNB江 2 電子還元を受けていることを示し た. PDA，MDH 执よびこれら化合物に打汀る関与電子 数はサイクリックボルタンメトリー掠よびクロノポテンシ オメトリーによってる確諗された。ただしこていらの関与 電子数忹, 水分含有量により異なり，上記值は，水分 200

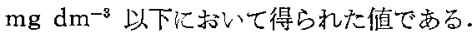

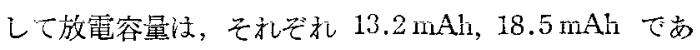
った・また放電終了後，リチ少極，黒鉛極を新しいも

*4 活物質をあらかじる溶解させた場合の自己放電速度およ び放電時の電位は，合刘を作成した場合と異なるが，自己 放電の難易孛調べる目的で, 一種の加速試験として過酷な 条件下で行なった. 
のと取り替えても放電容量を示さなかった. MAH, $m-$ DNB もほぼ同様な結果を示した.しかし，PDA の場 合には, 図より明らかに $2.1 \mathrm{~V}$ 程度の作動電圧を示し, さらに放電を続けた場合, 250 時間後の閉路電圧は, $1.9 \mathrm{~V}, 480$ 時間後の閉路電圧は, $1.4 \mathrm{~V}$ であった. PDA の仕込み容量は，2 電子反応を仮定した場合 $268 \mathrm{mAh}$ であり，Li/PDA 電池の放電終止電圧を $1.4 \mathrm{~V}$ とすれ ば, 放電容量は $228 \mathrm{mAh}$ となる.このことより溶解し たPDA はほとんど黑鉛極上で還元を受けており PDA のリチウム負極との反応による自己放電は，ここで検討 した他の有機活物質に比べて非常に小さいことが分かっ た. また, 放電進行に伴う顕著なガス発生および電解液 の色調変化は観察されず放電終了後の黒鉛極の表面には 樹脂状の青色固体が $3 \mathrm{~mm}$ 程度の厚さで析出していた.

\section{4 結 論 (Conclusion)}

高エネルギー密度リチウム非水溶媒電池用正極活物質 としての無水ピロメリト酸 (PDA) の適用性を $1 \mathrm{M}$ $\mathrm{LiClO}_{4} / \mathrm{PC}$ 溶液中での単極放電実験によって検討し, この結果を他の 2,3 の有機化合物で得られた結果と比 較した. その結果, PDA は, 電池正極活物質としての 活性を示し, $\mathrm{MAH}, \mathrm{TCNE}, \mathrm{DDQ}, m-\mathrm{DNB}$ などに比 ベて電解液中に溶解した活物質がリチウムと反応するこ とによって生じる自己放電が著しく小さく, リチウム電 池用正極活物質として有望であることを示した。

本研究は, 文部省科学研究費補助金 (試験研究) および旭硝 子工業技術奨励会助成金により行なった：ここに付記して感謝
を捧げる。

<1765> (Received Apr. 19, 1978)

$$
\text { 文献 }
$$

1) H. Alt and H. Binder, Electrochim. Acta 17, 873 (1972).

2) G.M. Jackson and J.S. Derecka, J. Electrochem. Soc. 112, 1218 (1965).

3) J.S. Dunning and D.N. Bennion, ibid. 117, 485 (1970).

4) J.S. Dunning and D.N. Bennion, ibid. 118, 1416 (1971).

5) B.L. Williams and J.J. Byrne, ibid. 116, 2 (1969).

6) Japan Kokai., 80,928 (1976).

7) U.S. Pat., 3,804,675 (1974).

8）小规 勉, 竹原善一郎, 吉沢四郎, 電爻化学 46, 407, 411 (1978).

is 5

\section{Pyromellitic Dianhydride as a Cathode Active Material for Lithium Nona- queous Cell}

Tsutomu Ohzuku*, Hisashi Wakamatsu **, ZenichiroTakehara** and Shiro YoSHIZAWA $* *$ (* Department of Synthetic Chemistry, Faculty of Engineering, Okayama University, Tsushima, Okayama; ** Department of Industrial Chemistry, Faculty of Engineering, Kyoto University, Yoshidahonmachi, Sakyo-ku, Kyoto) 